\title{
Spanien: Hvad indad tabes skal udad vindes
}

\section{John Schmidt}

Formandskabet overdrages i en tid, hvor Spanien er i en meget stram økonomisk situation. Det bliver kompliceret og der satses højt, for succes eller fiasko vil have stor betydning for Spanien og for premierminister José Luis Zapatero

1. januar blev det Spaniens tur til at besætte posten som turnus-præsident i EU, og ministerpræsident José Luis Zapatero indtrådte i det politiske triumvirat, som efter Lissabon-traktaten leder Unionen. En ordning der kan være lige så vanskelig at forklare som den Hellige Treenighed.

Personligt fik Zapatero en god start ved sin indledende tale til Rådet. Den tidligere universitetsprofessor holdt sit indlæg uden manuskript, hvilket i sig selv imponerede mange, som dermed fik demonstreret hans intellekt og grundige viden om Unionens opgaver og problemer. Begge områder er mange og besværlige. Indadtil skal løses problemer i forbindelse med den ændrede struktur og de forskellige syns- punkter om den politiske og økonomiske udvikling. Udadtil står man over for vanskelige forhandlinger med Tyrkiet, og det hele gøres ikke nemmere af, at USA synes at have skubbet Europa lidt til side og givet prioritet til relationerne til fx Kina, Indien og Brasilien.

Præsident Barack Obama bekendtgjorde, at han ikke kunne deltage i det planlagte topmøde mellem EU og USA i maj, hvilket af mange iagttagere blev opfattet som lidt af en fornærmelse mod EU i almindelighed og værtslandet Spanien i særdeleshed. De spanske oppositionspartier så det som en kold skulder til Zapatero, men samme Zapatero blev inviteret til præsidentens årlige 'prayer-breakfast' - en ære der tidligere er overgået så forskellige som 
Tony Blair og Mother Teresa, og Obama kaldte Zapatero 'my dear friend'. Varmere toner end i George W. Bushs tid!

\section{Image-problem}

Formandskabet overdrages i en tid, hvor Spanien er midt i en meget stram økonomisk situation, der naturligvis har politiske dimensioner såvel indad som udad. Landet oplevede i en snes år i slutningen af forrige århundrede et vældigt $ø$ konomisk opsving bl.a. på grund af byggeindustriens uhæmmede grådighed, men også ved dristig indsats af kapital og erhvervsmæssigt initiativ.

Alt tegnede såre lykkeligt, men da verdensøkonomien kom i klemme, bristede boblen, og resultatet er bl.a. en arbejdsløshedsprocent på ca. 20.

Da landet samtidig er vært for flere hundredetusinder udenlandske arbejdere - især fra Sydamerika - er såvel industri som handel og servicefag kommet i en truende økonomisk situation. Det går ligeledes ud over diverse pensionssystemer, som rejser tvivl om statens evne til at bevare og udbygge sine sociale forpligtelser.

På det nys overståede Davos-møde blev Spanien udsat for kritik og mødt med pessimisme fra flere sider. Den internationale økonomiguru Nouriel Roubini - også kaldet Dr. Doom - har udtalt, at Spanien er på vej mod et sammenbrud, mens andre eksperter er mere nuancere- de og mener, at Spanien behandles uretfærdigt. Der gøres opmærksom på, at Spaniens økonomi er verdensomfattende og flerdelt, samt at de spanske banker er kommet rimeligt godt igennem krisen. Mindre banker har lidt samme skæbne som andre hårdt ramte på grund af optimistiske huslån, men de større banker har klaret skærene, og fx den største spanske bank, Santander, har opkøbt flere britiske og amerikanske banker, der var i vanskeligheder.

Forholdene har imidlertid klart vist, at Spanien har et image-problem, som må tages alvorligt. Dette problem bliver ikke hjulpet af, at den spanske interne politiske situation og debat er ret så primitiv, præget af hykleri, vulgære personangreb og særdeles forenklede synspunkter om samfundets indretning. Den interne tilstand følges med ildhu af visse udenlandske medier, hvis interesse det er at se Spanien i hundehuset.

Zapatero og hans regering har iværksat forskellige forholdsregler for at overkomme krisen, bl.a. en økonomisk spareplan på 50 mio. euro over en treårig periode og en regulering af arbejdsmarkedet. Disse forholdsregler er ikke blevet mødt med begejstring af diverse interesseorganisationer, men de er nødvendige skridt for at overkomme krisen.

For 25 år siden stod den socialistiske regering under Felipe Gonzales over for en lignende situation, som 
han klarede ved stærk ledelse, politisk såvel som økonomisk. Det vil hurtigt vise sige om Zapatero har det nødvendige format. Ca. 75 pct. af spanierne er kritiske over for regeringens håndtering af krisen, hvilket ikke er mærkeligt i et land, hvor demokrati opfattes meget forskelligt. Den politiske debat er ikke så meget mellem modstandere i den demokratiske proces, som det er direkte fjendskab, hvor hensigten helliger midlet.

De seneste meningsmålinger viser, at det konservative oppositionsparti, Partido Popular, snævert har overhalet regeringspartiet, men viser også at Zapatero vurderes betydeligt $h ø$ jere end hans konservative modpart, Mariano Rajoy, hvis mangel på karisma er åbenbar.

\section{Ambitiøse EU-planer}

Zapatero har sat sig ambitiøse mål for formandskabet i EU for bl.a. derigennem at forbedre sit eget og sit partis image. Der er planlagt ikke mindre en ni internationale topmøder, fx med USA, Latinamerika og Middelhavsregionen. Det førstnævnte skal finde sted i maj måned, men er altså allerede lidt devalueret gennem Obames manglende deltagelse. For at få impulser og råd inviterede Zapatero nogle socialistiske sværvægtere til et møde i Madrid bl.a. Jacques Delors, Felipe Gonzales og Pedro Solbes - alle med enorm erfaring i EU-anliggender.
Indadtil i EU vil Spanien arbejde for at styrke Lissabon-traktaten, som jo først nu skal til at virke. Spanien har altid været en solid forkæmper for Europa og vil forsøge at påvirke medlemsstaterne med sin entusiasme. Man ønsker et smidigt og effektivt apparat, der desuden er åbent for borgerne. Man ønsker at koncentrere sig om de 'reelle' problemer og vil engagere sig i problemerne om de klimatiske forandringer, dvs. arbejde for 'grøn energi' som en garanti for de kommende generationer. Man vil ligeledes stræbe efter en bedre koordinering af den $\varnothing$ konomiske politik for at styrke og give impuls til en europæisk økonomisk genopblussen. Og man vil arbejde for en fuld garanti af menneskerettighederne og styrke kvindernes stilling.

Spanien vil arbejde for, at EU taler med én stemme over for den øvrige verden og ønske en komplet samarbejdet udenrigspolitik. Man $\varnothing n s k e r$ at styrke rollerne for EUpræsidenten og EU-udenrigsministeren, og man vil tage de første skridt imod en fælles diplomatisk repræsentation herunder et fælles diplomatisk korps.

Det er i dette lys man skal se de ni topmøder. Mødet i maj med USA anses for særdeles vigtigt, og det er beklageligt, at præsident Obama ikke selv kan være tilstede. USA har $i$ årtier ønsket at have en europæisk parter, man kunne tale med - 'ringe til’ som Henry Kissinger sagde - og 
det er nødvendigt, at de to parter reder diverse tråde ud. Det er en del iagttageres indtryk, at USA nu holder sig lidt tilbage, og man mener at spore en vis mistanke om, at EU vil forsøge at indtage en førende position på verdensscenen, hvilket USA ikke er indstillet på. Det er derfor vigtigt, at de to parter koordinerer deres interesser og ser hinanden $\mathrm{i}$ øjnene som ligemænd.

To andre vigtige topmøder er med henholdsvis Latinamerika og Middelhavsregionen. Spanien har særlige historiske forudsætninger for at skabe bro mellem Europa og Latinamerika. I de senere år er der udviklet stadig snævrere politiske og økonomiske bånd, som vil være af værdi for hele EU. Selv med hensyn til Cuba-problemet kan Spanien give den øvrige verden en håndsrækning. Spanien har særdeles gode relationer til den kommende sværvægter Brasilien og vil også her kunne støtte det øvrige EU.

\section{Mellemøsten og Tyrkiet}

Gennem Middelhavsregionen skabes der muligheder for, at de arabiske stater og Israel kan nærme sig hinanden med henblik på at finde en endelig løsning af Palæstina-problemet. Spanien har snævre bånd til flere arabiske stater og desuden et stabilt forhold til Israel. Den spanske udenrigsminister Miquel Angel Moratinos nyder almindelig respekt for sin dybe indsigt i forholdene og kan medvirke til, at Spanien opfattes som en 'honest broker'.

Umiddelbart står man over for tiltrædelsesforhandlinger med Tyrkiet. Spanien er principielt tilhænger af Tyrkiets indlemmelse af politiske hensyn og som en naturlig positiv behandling af en NATO-partner, som i mange år har ydet Alliancen store tjenester. De europæiske lande er dog delte i dette spørgsmål, så det vil være nødvendigt med en tålmodig og pragmatisk holdning.

Spaniens halvår bliver kompliceret og udfordrende. Der satses højt, og der vil blive lagt et kæmpearbejde i sagen. Regeringen har kastet sig ufortrødent ud i opgaverne. Succes eller fiasko vil have stor betydning såvel for Spanien som for regeringspartiet - og ikke mindst José Luis Zapatero.

John Schmidt er journalist. Han er bosat $i$ Spanien og har i mange år fulgt spansk politik på narmeste hold. 
Derfor frygter Kina internettet...

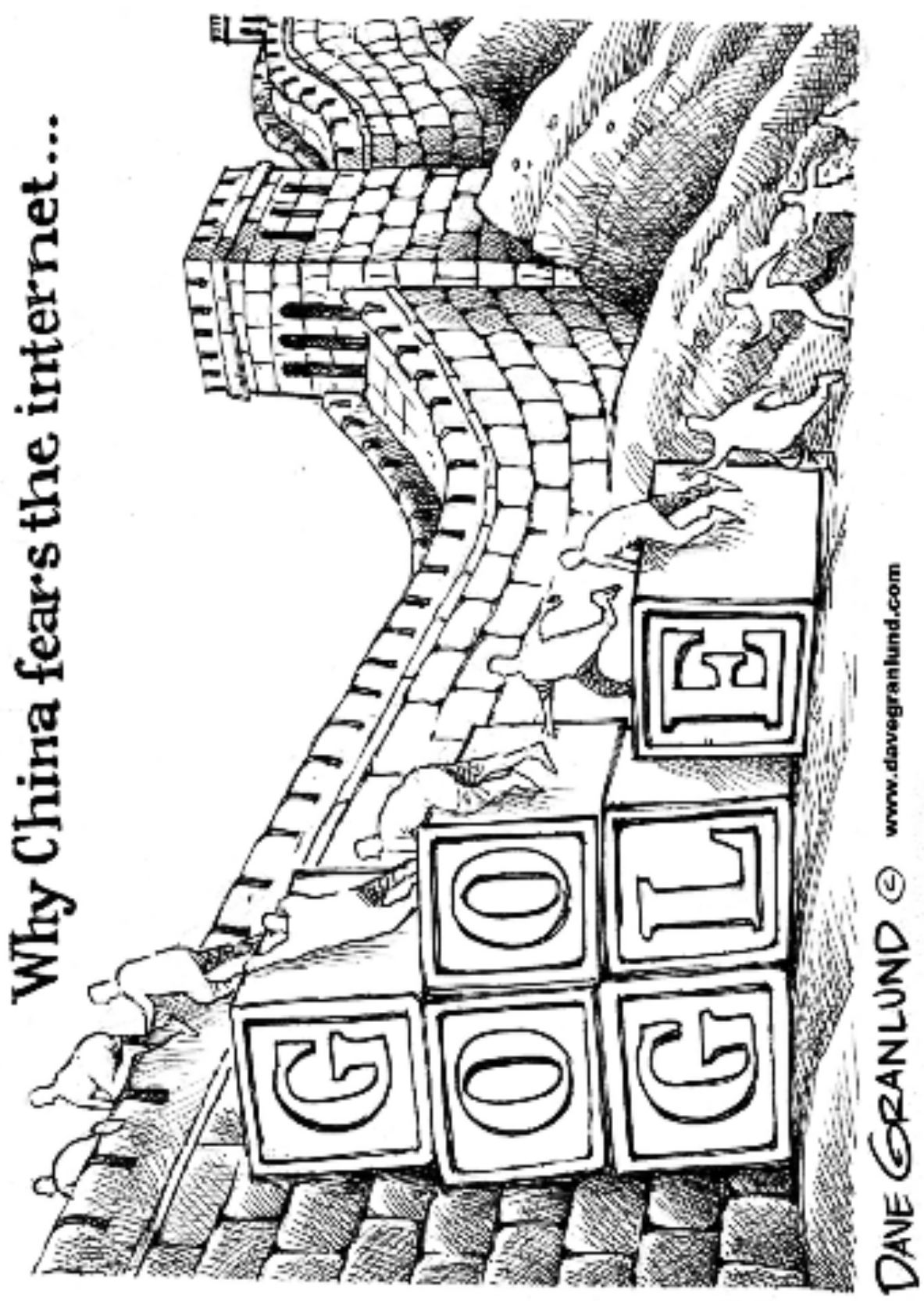

(c) Copyright 2010 Dave Granlund - All rights reserved.

udenrigs $1 \cdot 2010$ 